\title{
PENERAPAN PEMBELAJARAN KOOPERATIF TERPADU NHT DAN TSTS DALAM MENGATASI KESULITAN BELAJAR STRUKTUR ATOM DAN SISTEM PERIODIK UNSUR
}

\section{APPLICATION OF INTEGRATED COOPERATIVE LEARNING OF NHT AND TSTS IN OVERCOMING THE DIFFICULTY OF ATOM STRUCTURE LEARNING AND ELEMENTS PERIODIC SYSTEM}

\author{
Mukhtar Haris, Muntari, I Nyoman Loka \\ Pendidikan Kimia FKIP, Universitas Mataram, Indonesia \\ Email: mukhtar_haris@yahoo.co.id.
}

Diterima: 18 Juni 2019. Disetujui: 24 Juni 2019. Dipublikasikan: 30 September 2019

\begin{abstract}
Abstrak. Pada tahun 2013 peneliti telah mengembangkan perangkat pembelajaran kimia dengan menggunakan model pembelajaran kooperatif terpadu Numbered Head Together (NHT) dan Two Stay Two Stray (TSTS). Hasil penelitian pada tahun 2013 di SMAN 7 Mataram dan SMAN 3 Mataram menunjukkan bahwa: a) guru kimia belum pernah melakukan pembelajaran kooperatif dan hanya beberapa siswa yang aktif saat pembelajaran berlangsung, $b$ ) lebih dari 50\% siswa mengalami kesulitan belajar pada materi struktur atom, sistem periodik unsur, dan ikatan kimia. Pada tahun 2014, perangkat pembelajaran kimia tersebut diimplementasikan di kelas X guna mengetahui efektifitasnya. Hasil penelitian pada materi struktur atom dan sistem periodik unsur adalah: a) pembelajaran pada kelas eksperimen belum menunjukkan hasil yang berbeda secara signifikan dengan kelas kontrol dalam mengatasi kesulitan belajar siswa kelas X memahami konsep-konsep kimia. Rata-rata kesulitan belajarnya hampir sama yaitu sebesar 53,53\% dan 55,15\%, b) kelas eksperimen memiliki kesulitan belajar lebih rendah daripada kelas kontrol pada 8 indikator dari 12 indikator pemahaman materi struktur atom dan sistem periodik unsur
\end{abstract}

Kata kunci: Pembelajaran kooperatif terpadu, NHT, TSTS, kesulitan belajar

\begin{abstract}
In 2013 researchers have developed a chemistry learning device using integrated cooperative learning model Numbered Head Together (NHT) and Two Stay Two Stray (TSTS). The results of the research in 2013 at SMAN 7 Mataram and SMAN 3 Mataram showed that: a) the chemistry teacher has not been doing cooperative learning and only a few students who are active during the learning, b) more than $50 \%$ of students experiencing learning difficulties in the material of atomic structure, the periodic system of elements and chemical bonding. In 2014, the chemistry learning device is implemented in class X in order to determine its effectiveness. The results of the research in the material of atomic structure and the periodic system of elements: a) learning in atomic structure and the periodic system of elements in the experimental class has yet to show significantly different results with the control class in overcoming the learning difficulties of class X student in understanding the concepts of chemistry. On average the learning difficulties is almost same that is equal to $53.53 \%$ and $55.15 \%$, b) experimental class has learning difficulties a lower than the control class on 8 indicators of the 12 indicators in the understanding of atomic structure and the periodic system of elements materials
\end{abstract}

Keywords: Integrated cooperative learning, NHT, TSTS, learning difficulties

\section{PENDAHULUAN}

Kesulitan belajar ilmu kimia khususnya dan IPA umumnya bersumber pada: a) kesulitan memahami istilah, b) kesulitan memahami rumusrumus dalam perhitungan kimia, dan c) kesulitan memahami konsep-konsep kimia [1]. Khusus kesulitan memahami konsep kimia, timbul karena konsep-konsep dalam ilmu kimia bersifat abstrak dan kompleks sehingga siswa dituntut untuk memahami konsep-konsep tersebut dengan benar dan mendalam.

Ilmu kimia untuk siswa kelas X SMA berdasarkan Kurikulum 2013 diantaranya adalah tentang struktur atom, sistem periodik unsur, dan ikatan kimia. Hasil penelitian pada guru kimia kelas $X$ di SMAN 7 Mataram dan siswa kelas X di SMAN 3 Mataram dan SMAN 7 Mataram yang telah dilakukan peneliti menunjukkan bahwa [2]:

a) Terdapat beberapa masalah pembelajaran kimia dan masalah siswa yang perlu diatasi agar tidak menimbulkan masalah siswa kesulitan belajar kimia diantaranya adalah guru kurang melakukan hal-hal berikut: menunjukkan bahwa dirinya telah menguasai materi pelajaran kimia, menggunakan media secara efektif, dan belum 
pernah melakukan pembelajaran kooperatif. Sedangkan masalah siswa terutama adalah hanya beberapa siswa yang aktif saat pembelajaran berlangsung

b) Terdapat beberapa kesulitan belajar siswa dalam memahami konsep-konsep kimia terutama yang lebih dari 50\% siswa mengalami kesulitan belajar pada materi struktur atom \& sistem periodik unsur berupa kesulitan belajar dalam hal memahami tabel periodik unsur, menentukan elektron valensi, menentukan jumlah netron dan elektron dari ion, dan kesulitan menentukan golongan dan periode unsur

Berdasarkan hasil penelitian di atas, peneliti pada tahun 2013 telah mengembangkan perangkat pembelajaran kimia (RPP, buku ajar, dan instrumen penilaian) pada kedua materi pelajaran kimia tersebut dengan menggunakan model pembelajaran kooperatif terpadu Numberd Head Together dan Two Stay Two Stray dalam upaya mengatasi kesulitan belajar siswa kelas X SMA memahami konsep-konsep kimia.

Langkah-langkah pembelajaran kooperatif tipe NHT (Numbered Head Together) dan tipe TSTS (Two Stay Two Stray sebagai berikut [3]:

a. NHT (Numbered Head Together) atau Kepala Bernomor

1. Siswa dibagi dalam kelompok. Setiap siswa dalam setiap kelompok mendapat nomor

2. Guru memberikan tugas dan masing-masing kelompok mengerjakannya

3. Kelompok memutuskan jawaban yang dianggap paling benar dan memastikan setiap anggota kelompok mengetahui jawaban ini

4. Guru memanggil salah satu nomor. Siswa dengan nomor yang dipanggil melaporkan hasil kerja sama mereka.

b. Two Stay Two Stray (TSTS) atau Dua Tinggal Dua Tamu (DTDT):

1. Siswa bekerja sama dalam kelompok berempat seperti biasa

2. Setelah selesai, dua orang dari masingmasing kelompok meninggalkan kelompoknya dan masing-masing bertamu dua orang dari kelompok yang lain

3. Dua orang yang tinggal dalam kelompok bertugas membagikan hasil kerja dan mereka ke tamu mereka

4. Tamu mohon diri dan kembali ke kelompoknya dan melaporkan temuan mereka dari kelompok lain

5. Kelompok mencocokkan dan membahas hasil-hasil kerja mereka
Berdasarkan langkah-langkah NHT dan TSTS di atas, maka peneliti menggabung kedua teknik tersebut sebagai berikut:

1. Siswa dibagi dalam kelompok berempat. Setiap siswa dalam setiap kelompok mendapat nomor

2. Guru memberikan tugas dan masing-masing kelompok mengerjakannya

3. Kelompok memutuskan jawaban yang dianggap paling benar dan memastikan setiap anggota kelompok mengetahui jawaban ini

4. Setelah selesai, dua orang dari masing-masing kelompok meninggalkan kelompoknya dan bertemu dengan dua orang dari kelompok yang lain yang memiliki nomor yang sama

5. Dua orang yang tinggal dalam kelompok bertugas membagikan hasil kerja dan mereka ke tamu mereka yang memiliki nomor yang sama

6. Tamu mohon diri dan kembali ke kelompoknya dan melaporkan temuan mereka dari kelompok lain

7. Kelompok mencocokkan dan membahas hasilhasil kerja mereka

8. Guru memanggil salah satu nomor. Siswa dengan nomor yang dipanggil melaporkan hasil kerja sama mereka.

Selanjutnya pada tahun 2014, perangkat pembelajaran kimia tersebut diimplementasikan di kelas X guna mengetahui efektifitasnya, kemudian dilakukan revisi untuk menghasilkan perangkat pembelajaran yang lebih bermakna sebelum digunakan/disebarkan untuk sekolah-sekolah lain. Keutamaan penelitian ini adalah mengembangkan pembelajaran kooperatif terpadu Numberd Head Together dan Two Stay Two Stray dan membantu siswa dalam mengatasi kesulitan belajar memahami konsep-konsep kimia.

Mengacu pada Kurikulum 2013, materi pembelajaran struktur atom dan sistem periodik unsur untuk kelas X SMA meliputi: partikel-partikel penyusun atom, nomor atom dan nomor massa, isotop, isobar, isoton, perkembangan model atom, konfigurasi elektron \& diagram orbital, bilangan kuantum \& bentuk orbital, dan sistem periodik unsur.

Dengan demikian, konsep-konsep penting yang perlu dikuasai siswa dalam mempelajari struktur atom dan sistem unsur adalah sebagai berikut: a) notasi atom, b) jumlah partikel (proton, elektron, netron) dari suatu atom dan ion, c) unsur-unsur yang merupakan isotop, isobar, dan isoton, d) massa atom relatif dari isotop-isotop, e) model-model atom, f) konfigurasi elektron pada kulit atom, g) konfigurasi elektron pada sub kulit atom, h) elektron valensi, i) diagram orbital, j) bilangan kuantum, k) perioda, 1) golongan, dan $\mathrm{m}$ ) sifat-sifat periodik unsur

Penelitian tentang kesulitan belajar, kesalahan konsep, dan pembelajaran kooperatif telah 
dilakukan oleh peneliti, diantaranya membandingkan kesulitan belajar struktur dan tata nama senyawa kompleks sebelum dan sesudah pembelajaran kooperatif tipe NHT [2], peningkatan pemahaman kimia melalui paduan pembelajaran kooperatif tipe LT dan pemecahan masalah kimia dengan teknik Pathway [4], pembelajaran kooperatif berkirim salam dan soal untuk mengatasi kesalahan konsep stoikiometri [5], analisis kesulitan belajar ikatan kimia ditinjau dari kesalahan konsep siswa [6], perbandingan hasil pembelajaran kimia dengan menerapkan strategi pembelajaran kooperatif dan pembelajaran langsung [11], pembelajaran kooperatif tipe DTDT (TSTS) dalam mengatasi kesalahan konsep dan kesulitan mahasiswa pada konsep-konsep dasar reaksi kimia anorganik [8], pembelajaran kooperatif tipe bertukar pasangan dalam meningkatkan prestasi belajar ikatan kimia pokok bahasan ikatan kovalen [9], dan analisis kesalahan konsep dan tingkat kesulitan mahasiswa pada konsepkonsep dasar reaksi kimia anorganik [10].

\section{METODE PENELITIAN}

Penelitian ini adalah penelitian tahun kedua yang merupakan penelitian eksperimen menerapkan perangkat pembelajaran yang dihasilkan pada tahun pertama. Penelitian dilaksanakan pada Bulan JuniNopember 2014 di SMAN 7 Mataram. Rancangan penelitian ini digambarkan dengan diagram alir berikut:

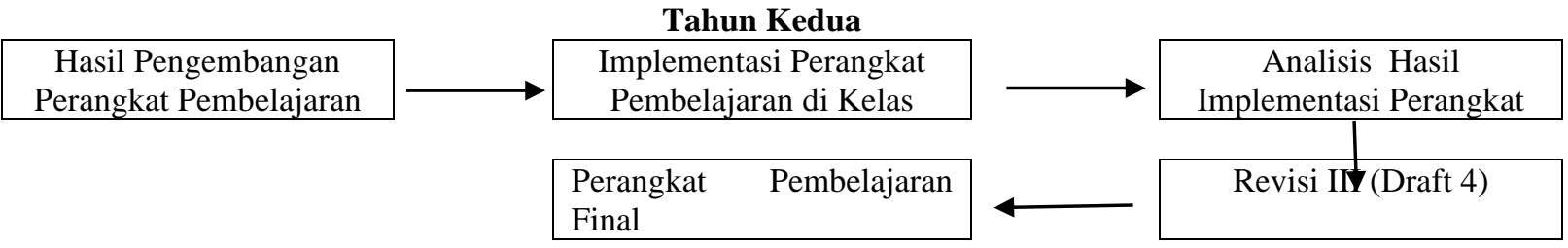

\section{HASIL DAN PEMBAHASAN}

Hasil penelitian ini berupa hasil analisis kesulitan belajar siswa kelas X memahami konsepkonsep kimia (struktur atom dan sistem periodik unsur) pada soal post test yang diberikan. Hasil analisis kesulitan belajar disajikan pada Tabel 1 .

Hasil penelitian pada Tabel 1 ini menunjukkan bahwa penerapan pembelajaran kooperatif terpadu Numbered Head Together dan Two Stay Two Stray dalam pembelajaran kimia materi pokok struktur atom dan sistem periodik unsur pada kelas eksperimen belum menunjukkan hasil yang berbeda secara signifikan dengan kelas kontrol dalam mengatasi kesulitan belajar siswa kelas X memahami konsep-konsep kimia, karena rata-rata kesulitan belajarnya hampir sama yaitu sebesar 53,53\% (kelas eksperimen) dan 55,15\% (kelas kontrol).

Pengaruh pembelajaran kooperatif terpadu Numbered Head Together dan Two Stay Two Stray dalam pembelajaran kimia materi pokok struktur atom dan sistem periodik unsur pada 12 indikator pemahaman siswa adalah kelas eksperimen memiliki kesulitan belajar yang lebih rendah daripada kelas kontrol pada 8 indikator. Kedelapan indikator tersebut adalah:

1. Menuliskan notasi atom suatu unsur.

Kesulitan belajar kelas eksperimen $(21,90 \%)$ lebih kecil dari kelas kontrol $(37,63 \%)$. Pada soal tentang atom $\mathrm{X}$ memiliki 19 proton, 20 neutron, dan 19 elektron. Siswa kelas eksperimen mampu menjelaskan cara menentukan nomor massa $=19+20=39$, namun salah dalam menentukan nomor atom, yaitu menulis notasi atomnya ${ }_{20}^{39} \mathrm{X}$ yang seharusnya adalah ${ }_{19}^{39} \mathrm{X}$. Sedangkan siswa kelas kontrol tidak memberi penjelasan cara menentukannya.

2. Menentukan jumlah partikel suatu unsur.

Kesulitan belajar kelas eksperimen $(48,57 \%)$ lebih kecil dari kelas kontrol $(67,74 \%)$.

Pada soal tentang menentukan banyaknya partikel pada ion ${ }_{11}^{23} \mathrm{Na}^{+}$, siswa kelas eksperimen mampu menjelaskan banyaknya proton $=11$, neutron $=23-11=12$, namun salah dalam menentukan banyaknya elektron = $11+1=12$, yang seharusnya $=11-1=10$. Sedangkan siswa kelas kontrol tidak memberi penjelasan cara menentukannya.

3. Menjelaskan pengertian isotop, isobar, dan isoton.

Pada indikator ini kesulitan belajar kelas eksperimen hampir sama dengan kelas kontrol yaitu $34,28 \%$ dan $38,71 \%$. Siswa kedua kelas mampu menentukan pasangan unsur yang isobar yaitu ${ }_{6}^{12} \mathrm{C}$ dan ${ }_{7}^{12} \mathrm{~N}$, namun mereka tidak memberikan penjelasan mengapa isobar.

4. Menentukan massa atom relatif.

Kesulitan belajar kelas eksperimen $(77,14 \%)$ lebih kecil dari kelas kontrol $(87,09 \%)$.

Siswa kelas eksperimen umumnya tidak memberikan penjelasan cara menentukan massa atom relatif unsur Fe yang memiliki massa rata- 
rata $=56$ sma, sedangkan kelas kontrol salah dalam menentukannya tanpa penjelasan

5. Menjelaskan sistem pengelompokkan unsur dalam tabel periodik unsur.

Pada indikator ini kesulitan belajar kelas eksperimen hampir sama dengan kelas kontrol yaitu $48,57 \%$ dan $50,00 \%$. Siswa kedua kelas salah dalam menentukan yang bukan sifat unsur golongan VIIA (sifatnya: non logam yang reaktif, memiliki 7 elektron valensi, dapat membentuk ion $\mathrm{X}^{-}$) dan nama golongan VA (golongan nitrogen)

6. Menentukan konfigurasi elektron suatu unsur.

Kesulitan belajar kelas eksperimen $(33,33 \%)$ lebih kecil dari kelas kontrol $(48,39 \%)$.

Siswa kedua kelas salah dalam menjelaskan konfigurasi elektron suatu unsur. Misalkan pada soal menentukan konfigurasi elektron dari ion $\mathrm{S}^{2-}($ nomor atom $=16)$.

Jawaban yang seharusnya adalah atom $\mathrm{S}$ bertambah 2 elektron sehingga konfigurasi elektronnya $=288$. Namun jawaban siswa yang salah bervariasi yaitu 286 (sesuai dengan nomor atomnya), 284 (karena melepas 2 elektron), atau 2842 (asal jawab).
7. Menentukan elektron valensi suatu unsur.

Kesulitan belajar kelas eksperimen $(60,00 \%)$ lebih kecil dari kelas kontrol $(74,19 \%)$.

Siswa kelas eksperimen salah dalam menentukan elektron valensi suatu atom yang mempunyai 21 netron dan nomor massa 40. Jawaban yang seharusnya adalah jumlah elektron $=40-21=19$. Konfigurasi elektronnya $=288$, maka ada 1 elektron valensi. Siswa menentukan elektron valensi dari jumlah netron $21=2883$, sehingga elektron valensinya $=3$. Sedangkan siswa kelas kontrol tidak memberi penjelasan cara menentukannya.

8. Menentukan kaitan konfigurasi elektron dengan bilangan kuantum

Kesulitan belajar kelas eksperimen $(81,42 \%)$ lebih kecil dari kelas kontrol $(87,09 \%)$.

Siswa kedua kelas salah dalam menjelaskan bilangan kuantum suatu unsur yang diketahui konfigurasi elektronnya. Misalkan pada soal menentukan bilangan kuantum elektron terakhir pada atom ${ }_{13}^{27} \mathrm{Al}$. Jawaban yang seharusnya adalah $\mathrm{n}=3, l$ $=1, \mathrm{~m}=-1, \mathrm{~s}=+1 / 2$.

Tabel 1. Hasil analisis kesulitan belajar siswa pada materi struktur atom dan sistem periodik

\begin{tabular}{|c|c|c|c|}
\hline & Kesulitan & jar Siswa & \\
\hline Indikator & Kelas & Kelas & Penyebab \\
\hline Pemahaman Siswa & $\begin{array}{l}\text { Eksperimen } \\
\text { (35 siswa) }\end{array}$ & $\begin{array}{l}\text { Kontrol } \\
\text { (31 siswa) }\end{array}$ & Kesulitan Belajar (umumnya) \\
\hline $\begin{array}{l}\text { 1. Menjelaskan perkembang-an } \\
\text { model atom ( } 2 \text { soal) }\end{array}$ & $40,00 \%$ & $16,12 \%$ & $\begin{array}{l}\text { Mengingat teori atom Bohr dan hasil } \\
\text { percobaan Rutherford }\end{array}$ \\
\hline $\begin{array}{l}\text { 2. Menuliskan notasi atom suatu } \\
\text { unsur ( } 3 \text { soal) }\end{array}$ & $21,90 \%$ & $37,63 \%$ & $\begin{array}{l}\text { Siswa kelas eksperimen salah dalam } \\
\text { menentukan nomor massa atau nomor } \\
\text { atom, sedangkan kelas kontrol tidak } \\
\text { memberi nenielasan cara menentukannva }\end{array}$ \\
\hline $\begin{array}{l}\text { 3. Menentukan jumlah } \\
\text { partikel suatu unsur ( } 2 \text { soal) }\end{array}$ & $48,57 \%$ & $67,74 \%$ & $\begin{array}{l}\text { Siswa kelas eksperimen salah dalam } \\
\text { menentukan jumlah partikel (proton, } \\
\text { elektron, neutron), sedangkan kelas } \\
\text { kontrol tidak memberi penjelas-an cara } \\
\text { menentukannya }\end{array}$ \\
\hline $\begin{array}{l}\text { 4. Menjelaskan pengertian } \\
\text { isotop, isobar, dan isoton } \\
\text { (1 soal) }\end{array}$ & $34,28 \%$ & $38,71 \%$ & $\begin{array}{l}\text { Siswa kedua kelas tidak mem-beri } \\
\text { penjelasan cara menentukan pasangan } \\
\text { unsur yang isobar }\end{array}$ \\
\hline $\begin{array}{l}\text { 5. Menentukan massa atom } \\
\text { Relatif ( } 1 \text { soal) }\end{array}$ & $77,14 \%$ & $87,09 \%$ & $\begin{array}{l}\text { Siswa kelas eksperimen tidak memberi } \\
\text { penjelasan, sedangkan kelas kontrol } \\
\text { salah dalam menentukan massa atom } \\
\text { relatif }\end{array}$ \\
\hline $\begin{array}{l}\text { 6. Menjelaskan sistem penge- } \\
\text { lompokkan unsur dalam tabel } \\
\text { periodik unsur ( } 2 \text { soal })\end{array}$ & $48,57 \%$ & $50,00 \%$ & $\begin{array}{l}\text { Siswa kedua kelas salah dalam } \\
\text { menentukan sifat unsur golong-an VIIA } \\
\text { dan nama golongan VA }\end{array}$ \\
\hline $\begin{array}{l}\text { 7. Membandingkan kecende- } \\
\text { rungan sifat-sifat unsur dalam satu } \\
\text { periode/golongan ( } 2 \text { soal })\end{array}$ & $81,42 \%$ & $74,19 \%$ & $\begin{array}{l}\text { Siswa kedua kelas tidak dapat } \\
\text { menentukan unsur yang memiliki jari- } \\
\text { jari atom terbesar dan sifat periodik } \\
\text { unsur dalam dalam satu periode }\end{array}$ \\
\hline
\end{tabular}


8. Menjelaskan pengertian

$45,71 \% \quad 12,90 \%$

bilangan kuantum dan orbital (1

soal)

9. Menentukan konfigurasi

elektron suatu unsur (3 soal)

10. Menentukan elektron

valensi suatu unsur (2 soal)

$\begin{array}{ll}45,71 \% & 12,90 \% \\ 33,33 \% & 48,39 \% \\ & \\ 60,00 \% & 74,19 \%\end{array}$

Siswa kedua kelas salah dalam menentukan subkulit dari bilangan kuantum $l=2$

Siswa kedua kelas salah dalam menentukan konfigurasi elektron suatu atom netral dan ion

Siswa kelas eksperimen salah menentukan elektron valensi, sedangkan kelas kontrol tidak memberikan penjelasan cara menentukannya

\section{KESIMPULAN}

Pembelajaran materi struktur atom dan sistem periodik unsur pada kelas eksperimen belum menunjukkan hasil yang berbeda secara signifikan dengan kelas kontrol dalam mengatasi kesulitan belajar siswa kelas X memahami konsep-konsep kimia, karena rata-rata kesulitan belajarnya hampir sama yaitu sebesar 53,53\% (kelas eksperimen) dan $55,15 \%$ (kelas kontrol)

\section{DAFTAR PUSTAKA}

[1] Arifin, M., 1995, Pengembangan Program Pengajaran Bidang Studi Kimia, Surabaya, Airlangga University Press.

[2] Haris, M., Loka, I.N., dan Al-Idrus, S.W., 2006, Penerapan Pembelajaran Kooperatif Tipe Bertukar Pasangan dalam Meningkatkan Prestasi Belajar Ikatan Kimia Pokok Bahasan Ikatan Kovalen pada Mahasiswa Program Studi Pendidikan Kimia FKIP Unram Tahun Pelajaran 2006/2007, Laporan Penelitian, FKIP Unram.

[3] Lie, Anita, 2003, Cooperative Learning, Jakarta, Grasindo.

[4] Muntari, 2007, Perbandingan Hasil Pembelajaran Kimia dengan Penerapan Strategi Pembelajaran Kooperatif dan Pembelajaran Langsung pada Siswa Kelas XI SMAN 1 Mataram, Laporan Penelitian, FKIP Unram.

[5] Anwar, Y.A.S dan Haris, M., 2008, Mengatasi Kesalahan Konsep Stoikiometri Melalui Pembelajaran Kooperatif Berkirim Salam dan Soal pada Mahasiswa Program Studi Pendidikan Matematika FKIP Unram Tahun Akademik 2007/2008, Laporan Penelitian, FKIP Unram.

[6] Haris, M. dan Al-Idrus, S.W., 2007, Analisis Kesulitan Belajar Kimia Pokok Bahasan Ikatan Kimia Ditinjau dari Kesalahan
Konsep Siswa pada Struktur Atom dan Sistem Periodik Unsur: Studi Kasus pada Siswa Kelas X SMA Negeri 3 Mataram Tahun Pelajaran 2007/2008, Laporan Penelitian, FKIP Unram.

[7] Haris, M. dan Al-Idrus, S.W., 2006, Analisis Kesalahan Konsep dan Tingkat Kesulitan Mahasiswa pada Konsep-Konsep Dasar Reaksi Kimia Anorganik: Studi Kasus pada Mahasiswa Program Studi Pendidikan Kimia FKIP Universitas Mataram, Laporan Penelitian, FKIP Unram.

[8] Haris, M. dan Al-Idrus, S.W., 2007, Penerapan Pembelajaran Kooperatif Tipe DTDT (Dua Datang Dua Tinggal) dalam Mengatasi Kesalahan Konsep dan Kesulitan Mahasiswa pada Konsep-Konsep Dasar Reaksi Kimia Anorganik, Laporan Penelitian, FKIP Unram.

[9] Haris, M., Loka, I.N., dan Al-Idrus, S.W., 2011. Membandingkan Kesulitan Belajar Struktur dan Tata Nama Senyawa Kompleks Sebelum dan Sesudah Pembelajaran Kooperatif Tipe NHT pada Mahasiswa Program Studi Pendidikan Kimia FKIP Unram, Laporan Penelitian, FKIP Unram.

[10]Haris, M., Muntari, dan Loka, I.N. 2013. Pengembangan perangkat pembelajaran kimia dengan model pembelajaran kooperatif terpadu Numbered Head Together dan Two Stay Two Stray dalam upaya mengatasi kesulitan belajar siswa kelas X SMA memahami konsep-konsep kimia. Laporan Penelitian. FKIP Unram.

[11] Muntari, 2009, Pengaruh Strategi Pembelajaran Pemecahan Masalah Kimia dengan Teknik Pathway terhadap Pemahaman Konseptual Algoritmik pada Siswa SMA dengan Kemampuan Matematika yang Berbeda. Laporan Penelitian, FKIP Unram. 